Dimitris Soudias - On the Spatiality of Square Occupations. Lessons from Syntagma and Tahrir

On the Spatiality of Square Occupations. Lessons from Syntagma and Tahrir.

\title{
Dimitris Soudias
}

Center for Near and Middle Eastern Studies, Philipps-Universität, Marburg, Germany

Soudias@uni-marburg.de

Pre-Print of book chapter published by Rowman \& Littlefield

https://rowman.com/ISBN/9781786603715/Riots-and-Militant-Occupations-Smashing-a-System-Buildinga-World-A-Critical-Introduction

Introduction

The year 2011 fractured a previously dismal landscape of street politics. The seditious emergence of the Arab Uprisings, Occupy, and the 'movement of the squares' brought forth mass manifestations of wrath and hope, illuminating the importance of reclaiming public space for social change. Observers were quick in pointing to the spatial aspects of the act of occupying squares (e.g. Harmanşah 2014; Marom 2013; Ramadan 2012; Stavrides 2012). But quite curiously, they tend do so passingly, despite the fact that a raft of different theoretical work has been done on the social production of space (e.g. Crang \& Thrift 2000; Löw 2008; Massey 1996). In my own work, I have tried to problematize the spatiality of protest (Soudias 2015; Soudias 2014) by relating conceptual discussions in the field of the sociology of space to that of social movement studies (SMS). But as is often the case in the process of research, the more we read and investigate, the more critical and nuanced we view our subject of study and our own work.

What I would like to do in this article, therefore, is to rethink the spatiality of square occupations. Methodologically (in a rather rudimentary sense), I intend to do so through what Turner (2014) termed bricolage. Building on Claude Lévi-Strauss, Turner conceives bricolage as puttering, as a synthetic work in which the researcher establishes "a kind of coherence between available theoretical ideas" (132). In this sense, I will first reflect on how space, place, presence, and territoriality are constituent conceptual notions of square occupations' spatiality. Building on de Certeau's notion of "Making Do" (2002), and drawing heavily from Syntagma and Tahrir as examples, what follows then is an elaboration on the role of policing strategies and protest tactics as means of tabulating and imposing, or diverting and manipulating space.

The cases of the 2011 occupations of Syntagma Square in Athens, and Tahrir Square in Cairo will serve the purpose of anecdotal evidence to exemplify the aforementioned concepts empirically. This evidence is mainly made up of in-depth conversations with participants of both occupations ${ }^{1}$ and my own

1 For reasons of confidentiality, all the participants have been given pseudonyms. 
Dimitris Soudias - On the Spatiality of Square Occupations. Lessons from Syntagma and Tahrir

participation in the January 25 uprising in Cairo. ${ }^{2}$ Before jumping into the conceptual discussion, let us bring the characteristics of the Tahrir and Syntagma occupations back to memory.

Tahrir and Syntagma: A Brief Overview

The specific crisis contexts leading to the occupations of Syntagma and Tahrir, as well as the particular demands of those in the squares vary in both cases. They have been explicated elsewhere for Egypt (Abdelrahman 2015; Korany \& El-Mahdi 2012; Soudias 2014) and Greece (Douzinas 2012; Giovannopoulos and Mitropoulos 2012; Souliotis 2013) alike and reiterating them would go beyond the scope of this paper. If we translate both cases to their most basic virtues, they are liminal, spatially manifested expressions of contestation against the status quo, and for something different entirely. From this viewpoint, and in light of their spatiality, looking at both occupations brings forward some intriguing empirical similarities. Both occupations were staged in the heart of the capital city. People took their discontent to these places and stayed. And they did so over an extended period of time.

In Tahrir, after appropriating the square, protesters set up tents as places of retreat and recreation. They set up infrastructure to maintain their occupation and sustain their presence. There were specific committees for e.g. media communication, food, medical care, waste management, security, or childcare, for organization; and Hyde Park-like speakers' corners and stages with large speakers as places of expression. Protesters established at least three levels of security checkpoints at each entrance to the square, checking IDs and bags to make sure no thugs or plainclothes agents entered. Makeshift barricades and rocks made out of pavement were set up neatly to ward off potential attacks. Hundreds of sympathizers who did not camp out on the square brought in supplies such as blankets, bread, and water in order to sustain the occupation, but also onions, vinegar and first-aid kits against teargas and injuries. The occupation was leaderless, for the most parts anti-hierarchical and, as Bamyeh (2013) notes, anarchist in method. Although not formalized, decisions were taken collectively and organizational needs were developed 'on the go' in response to new situations. Security forces were policing the occupation mainly through violent repressive strategies, including the use of teargas, rubber bullets, and even live rounds. They deployed thugs and plainclothes-agents (Soudias 2015), but found it impossible to dissolve the

2 I returned to Cairo in 2010 for the general elections in November to do fieldwork for my project "Negotiating Space: The Evolution of the Egyptian Street, 2000-2011." As the elections tended to be rigged under Mubarak, I expected protests to occur. Yet, while the only thing transparent about these elections was in fact their fraudulence, there was little contestation. I decided to stay regardless to talk to activists and observe smaller protests' dynamics of tactical repertoires and policing strategies. In light of the developments in Tunisia in December, I extended my stay, allowing me to witness the January 25 Uprising in Cairo first hand. 
occupation. People stayed and fought off security forces successfully in multiple occasions. ${ }^{3}$ Tahrir was in many ways a space of Communitas in Viktor Turner's sense.

In Syntagma, protesters also demarcated territory through occupying the square and setting up structures. But unlike in Tahrir, there was a more clearly defined cleavage among participants in Syntagma, which was expressed by participants' talk of the demarcation between the 'upper' (Amalias Ave and Parliament) and the 'lower' square (around the fountain). In that narrative, the upper square was one of bodily practices and protest rituals (such as chanting, clapping, cheering, dancing), one with a carnivalesque mood and a more stadium-like atmosphere and psychology (Stavrou 2011). The lower square on the other hand, has been claimed by their participants and the Left more generally as that of political vision, organization, and assembly. It was mainly here that occupational infrastructure was established and maintained in the face of perpetual police violence. Quite interestingly, the division of labor, organization, and decision-making processes were more refined and less ad-hoc here than in Tahrir. There were over two-dozen different groups in Syntagma that can be broadly separated into organizational and thematic groups. The organizational ones ensured the running of the occupation. They consisted of a welcome group, where people could get an overview and enlist in the other groups. These included the general secretariat, the technical support group, the multimedia group, the translation group, the medical clinic, the defense group, the "calming" group that resolved conflicts and tensions non-violently, the food and catering group, or the cleaning group amongst many others. The thematic groups were those putting forward creative performances and alternative visions of politics. These included the time bank (similar to Pierre-Joseph Proudhon's notion of the exchange bank), the artists' group, the group of work and unemployment, the direct democracy group, the group on eco-communities and alternative currencies, the group on the economy, that of education and many others. Decisions on political propositions or organizational issues were taken in the general assembly - the heart of the occupation - where everybody could directly partake, discuss, and vote upon them. Just like in Tahrir, the policing strategy by security forces was marked by violence. Although the intensity of violence was lower than in the case of Tahrir (i.e. no live rounds were fired and although many were injured, no one died during battles), the goal of the greater policing strategy was to drive out protesters and eventually evacuate the square, which they successfully did in late July.

These interactions and structures - the establishment of a group, the setting up of a barricade, the throwing of a teargas canister - are all enmeshed in the social production of space. But what do we mean when we speak of space and its social production? And what else is there to the spatiality of occupations other than being a terrain of resistance?

For a detailed narrative participant account of the January 25 uprising, see Soudias 2014, 103-129. 
Dimitris Soudias - On the Spatiality of Square Occupations. Lessons from Syntagma and Tahrir

\section{On Space}

To think of space as socially constructed is a viewpoint firmly situated in a post-modern, or poststructuralist discourse. Space here is broadly conceived in its dialectics as a structuring and structured structure (similar to the Bourdieusian conception), or, put differently, as the relationality between space and human agency (Foucault 1986; Lefebvre 2007). On the one hand, space is the product of agency. But it also shapes our practices and actions, which maintain and reproduce space. Scholars in the fields of critical geography and urban sociology point out that people act according to socio-cultural factors such as gender, class, 'race' or age 'within' and in reaction to space, but also create and modify particular spaces to express their own needs and desires (Gottdiener \& Hutchinson 2010, 19-21; Soja 1980).

Henri Lefebvre's work on the 'social production of space' is particularly fruitful for investigating occupations, as it underlines the dialectic of the social and the spatial as inseparably linked and mutually constitutive. In Lefebvre's conception, spaces are constructed through social relations and structures. Acknowledging that spaces are experienced in multiple ways, Lefebvre (2007: 33; 38-39; 245) identifies the triad of conceived space (representations of space), perceived space (spatial practice), and lived space (representational space); seeing a unity between the (abstract) cognitive, the (concrete) physical, and the social (see also: Elden 2004: 189-190; Martin \& Miller 2003: 146). Spaces such as squares and streets have been conceived, i.e. designed and planned through labor, technology and institutions. They are perceived in everyday life in their materiality and physicality. The meaning of such spaces, however, is adapted and transformed as they are lived by social actors. Lived space, then, is where perception and conception meet and interact, where "the imagination seeks to change and appropriate" (Lefebvre 2007: 39). Tahrir Square, for example, was conceived to emulate Place Charles de Gaulle in Paris ${ }^{4}$, a vision that was never fully implemented. Tahrir has arguably been perceived as a central and popular meeting spot, and lived as a hub of transportation, consumption and socializing on January 24 2011. But on January 25 2011, when the Egyptian uprising began, it has widely been lived as a space of protesting authority despite its initial conception (Schumann \& Soudias 2013; Telmissany 2014). How then, does this change occur and play out empirically?

\section{On Presence}

The basic premise for the transformation of spaces with regard to occupations lies in bodily presence (Schumann \& Soudias 2013). By being present in Tahrir or Syntagma, protesters partake in the production of spaces and transform them in action. To give an example: Describing the beginnings of the Syntagma

The Place Charles de Gaulle is part of Hausmann's renovation of Paris and its historic name "Place de l'Étoile" points to the star-like shape of the square designed to be a traffic junction. 
Dimitris Soudias - On the Spatiality of Square Occupations. Lessons from Syntagma and Tahrir

Square occupation, Victoria recalls that the decision to go to Syntagma was taken at the Spanish embassy in Athens' Thisseio neighborhood during the solidarity protests with the Spanish Indignados:

We went there [Syntagma] at $1 \mathrm{am}$. Some set up a tent. ... We didn't have a plan. We didn't know. ... And in the next morning ... I get up and go to Syntagma. There weren't any people. ... There were two people from the group of Thisseio who only brought a small tent and a small table. I brought my laptop. We set up the laptop. Just three people. ${ }^{5}$

By merely being present in the square and setting up tables and laptops, Viktoria and her comrades began transforming the setup and meaning of Syntagma towards something else. A few hours in, passers-by in Syntagma presumably perceived the square differently, got curious and engaged in conversations with the recently-turned occupiers. So did an elderly woman, as Viktoria recalls:

"What will you eat?" she says. "We will buy something", I tell her. She says "I will go cook with my girlfriends and I will bring you [food]" And she brought us Tupperware. And so the grandmother with her friends started the next group, which is the catering and cooking group. ${ }^{6}$

This may seem banal, but it underlines the relevance of presence as the prerequisite for space transformation. To be present allows for interactions and highlights the possibility for contemplation, discovery, epiphany, or imagination (Bamyeh 2013; Schumann \& Soudias 2013). And through such interactions, Syntagma or Tahrir were transformed into (lived) spaces of resistance. The various structures we saw in Syntagma and Tahrir, such as the medical clinics, or simply the setting up of barricades contribute to the production of these squares as spaces of resistance. Or to put it in more Lefebvrian terms: Through such actions, protesters use Syntagma and Tahrir other than their initial conception as traffic hubs, turning them into something else entirely, appropriated in use. Their 'orderly' use of merely 'passing by' these squares or meeting up with friends changes towards an 'exceptional' appropriation with changing actions, symbols, and discourses that can be broadly subsumed under the banner of resistance to the status

Viktoria, (participant of the Syntagma Square occupation 2011), in discussion with the author, October 222014.

6

Viktoria, (participant of the Syntagma Square occupation 2011), in discussion with the author, October 222014. 
quo ante.

These processes are not uncontested. As I will show below, protesters' presence (and the space transformation that comes with it) jeopardizes the use of these spaces according to their initial conception (conceived space). This is to say that it calls the police to the scene to enforce 'public order' through repressive policing strategies in an attempt to quell divergence. But before delving into territoriality and tactics/strategies, let us take a closer look at the role of place in relation to spatiality.

\section{On Place}

Why have square occupations occurred in the hearts of cities? Why do participants decide to take to central squares? Does it matter which places protesters occupy? For Haitham, the answer to this question for his native Cairo is self-evident:

\section{Everybody knows: When in doubt, go to Tahrir. ... I don't know if protesters organized it together to go to Tahrir or if they knew instinctively-because in 2003 [Iraq antiwar protest] that was where everyone met up in the end. ${ }^{7}$}

Haitham underlines the symbolic relevance of Tahrir. Building on sociologist Asef Bayat (2009, 167-169), I argue that protesters chose to take their dissent to such geographically central locations as Tahrir or Syntagma for a variety of interrelated reasons. Firstly, mobile crowds can rapidly assemble and disperse at large streets and squares. Tahrir, for example, can be reached from as many as 23 different streets and two bridges (AlSayyad 2011), making it impossible for security forces to seal off the square. Secondly, the downtown areas of Cairo and Athens hold historical and political significance, as most political institutions symbolizing state power are located there. ${ }^{8}$ Regarding institutions, Syntagma is right in front of the Vouli (the Greek Parliament), while the monstrous Mogamma government complex is adjacent to Tahrir. The

Haitham, (participant of the Tahrir Square occupation 2011), in discussion with the author, March 172011.

8

To give an idea: In Cairo, the headquarters of the former ruling party (NDP) were right by Tahrir. State TV and Radio, many ministries (including the much-despised ministry of interior), embassies, the headquarters of the Arab League, and the Egyptian Parliament are within walking distance. In Athens, the ministry of finance is right by Syntagma and many others are close by, while the Megaro Maximou, which is the official seat of the Greek Prime Minister, is less than 600 meters away from Syntagma. Immediately adjacent to Syntagma is the five-star hotel Grande Bretagne, which has a long history of housing political and military elites and was a sort of unofficial residence of the Troika. 
historical significance of these squares stems from uprisings that occurred in the area. What comes to mind in Cairo is the 1881 Urabi revolt at Abdeen square, or the 1977 bread riots in Tahrir square. In Athens, the Revolution of September 31843 against King Otto occurred at what is now Syntagma Square - formerly the forecourt to the King's Palace, which today is, quite cynically, the Greek Parliament. Similarly, violent clashes in the December Events in 1944 and 2008 alike took place in Syntagma. Thirdly, both squares serve as intersections for mass transportation networks, facilitating easier access and escape for potential protesters. And lastly, both Tahrir and Syntagma are at the center of media attention. AP is within walking distance to Syntagma, and Reuters even haven their offices next to the square. This allows protesters to extend their discontent beyond their immediate environment. Place, therefore, matters for spaces of resistance in that it is, together with presence, the prerequisite for their production. The symbolic, historical, and physical characteristics of place arrange patterns of face-to-face interaction that constitute collective action (such as square occupations), and in its relation to space "embodies otherwise intangible cultural norms, identities, memories and values" (Gieryn 2000, 473). This, then, can account for why Haitham suggests people tacitly "knew" why to take to Tahrir. The characteristics of place is also one amongst other factors that can help understanding why people would maintain their occupation in spite of repression. This brings us to territoriality and the claim to ownership.

\section{On Territoriality}

The claim to possessing location lies at the heart of territoriality or territorial control. According to Sack $(1986,19)$, territoriality defines "the attempt by an individual or group to affect, influence, or control people, phenomena, and relationships, by delimiting and asserting control over a geographic area." A premise of the modern nation state is its control over territory. The police are agents of enforcing this control. They are given a set of legal and coercive powers to enforce control in terms of Foucaultian disciplinary power. They represent authority through their physical presence at places and use their powers to (re-)produce/ maintain spaces according to particular sets of norms that can be broadly subsumed under 'public order'. ${ }^{9}$ Maintaining public order remains fundamental because it is "the test of a government's capacity to govern" (Anderson 2011, 155). Therefore, security forces attempt to prohibit protesters from constituting spaces of resistance through territorialization in order to maintain public order, i.e., the capacity to govern. As Herbert (1997, 6-10) notes,

Territorial control is an inherent outcome of the social organization of the police ... modern policing has meant the development of a capacity to intrude into and control

9

A discussion on the conception and practice of 'public order' is beyond the scope of this paper.

For this I therefore suggest to turn to Anderson (2011: 154 f.), who offers an exciting account of the term in his analysis of the French police. 
space ... officers can, when necessary, secure control of the flow of action in space. The police ... are expected to be effective agents of territoriality, to be able to control social action by controlling area.

If we think of the notion of social control in relation to Foucaultian governmentality, territoriality is a means of subjectification, of ensuring the docility of subjects in relation to the orders of the status quo. Many policing strategies involve enacting boundaries, restricting access and using force to create and maintain 'public order'. As Sack $(1993,327)$ notes, "social power cannot exist without these territorial rules. Territorial and social rules are mutually constitutive". Complementing Foucault's notion of disciplinary power, the capacity to use force is central to the role of the police. The nation state needs the capacity to exercise systematic control over its population in order to maintain itself. ${ }^{10}$ The state's authority and existence is dependent on "the capacity of the police to mark and enact meaningful boundaries, to restrict people's capacity to act by regulating their movements in space” (Herbert 1997, 13).

Territorialization, however, is not a unilinear but rather a contested and interactive process. Protesters appropriating squares by occupying them and thereby producing spaces of resistance are challenging state territoriality through their own practices of territorialization (Wahlström 2010, 813). This then, unsurprisingly, brings the police to the scene - more often than not packed with repressive strategies. The fact that protesters in Tahrir and Syntagma alike stayed in the square despite repressive policing signifies what Douzinas $(2013,153)$ righly frames with the Greek word Stasis, meaning "upright posture, standing tall and serene, holding your stance", but also insurrection or revolt. As opposed to protest marches or demonstrations, the Stasis of occupations allows for a sort of temporary territoriality. Stasis gives people a sense of ownership of place that more mobile forms of protest lack. Laila, for example, told me about Tahrir that "this [occupation] is ongoing and this place is ours! The tents are up. And even when the military takes them down, people put them back up. It's a sign that we are staying here!" ${ }^{11}$ Similarly,

10

In Egypt, this has been underlined with the matching legal framework of the Emergency Law. In place since President Sadat's assassination in 1982 until 2012, it allowed security forces to arrest people without charge, limit freedom of assembly and expression and effectively criminalized any kind of protest. In Greece, there is also an emergency law that has been used by the government to quell strikes and other forms of 'civil disobedience'.

11

Laila, (participant of the Tahrir Square occupation 2011), in discussion with the author, March 3 2011. 
Dimitris Soudias - On the Spatiality of Square Occupations. Lessons from Syntagma and Tahrir

Andreas said about Syntagma that "it was magical. We had a space where we felt it was ours. We lived there. If you live there, if you hold assemblies and if you discuss there, it is yours in some way."12

In this sense, the production of spaces of resistance and the stasis that comes with prolonged presence means to claim ownership of territory and physically locate autonomy (from state authority). Nabil illustrate how territorialization materialized in Tahrir:

Holding on to Tahrir ... was the biggest [issue] ... A lot of organization was very organic. [There were] people always at all the entrances of Tahrir and then they set up ... these Legan Sha'abeya [people's committees] where to get into Tahrir you had to show your passport or Egyptian ID a number of times to a number of different people. They were policing Tahrir in the absence of police. ${ }^{13}$

There are more obvious, more strategic reasons for territorial control as well, especially when locations with an immense political and organizational significance are at stake. During the January 25 uprising in Cairo, for example, the ministry of interior (which is home to the security forces) has been besieged and almost taken over. It took months for the security apparatus to resurrect (and they did and do so full of vengeance). In Athens, protesters also recognized this strategic significance as Aggelos recalls:

I think that it [the square occupation] happens in front of the parliament is important, that it happens in front of where decisions are taken, important ones. It would have been different in Omonoia [the second largest square in downtown Athens, close-by Syntagma]. But in front of the parliament, I think it has its importance. It's symbolic, but also real. There were attempts to get in there and to burn it down. ${ }^{14}$

To lose territorial control therefore also means to lose authority and sovereignty. Once Syntagma and Tahrir were taken over by protesters, the threshold of extending their discontent beyond the square shrank

12

Andreas, (participant of the Syntagma Square occupation 2011), in discussion with the author, February 112016.

13

Nabil, (participant of the Tahrir Square occupation 2011), in discussion with the author, March 21 2011.

14

Aggelos, (participant of the Syntagma Square occupation 2011), in discussion with the author, January 272016. 
Dimitris Soudias - On the Spatiality of Square Occupations. Lessons from Syntagma and Tahrir

significantly with public buildings and ministries occupied both in Athens and Cairo (cf. Soudias 2014; Douzinas 2013).

Although spatially manifested resistance goes hand in hand with territoriality, not everyone was happy with the underlying notion of social control, as Irini's example in Syntagma shows:

They brought their tents and in them they had their laptops. [...] then they established the defense group, so they would protect their laptops that were in their tents. They walked by, like cops, looking inside the tents (says this with disgust). This is when the system divided us. And this is when it was taken from us. Because when we are cops, we are divided. ${ }^{15}$

For Irini, the compartmentalization of Syntagma into groups eventually led her to stop coming to the square. Her mentioning of being "divided" I interpret as a result from this compartmentalization. Each group in Syntagma had their own place and role in the square. And with this place and division of labor - in addition to the fact of social control through the defense group - comes a sort of micro-territoriality that reproduces the very logics of social control Irini sought to challenge with her participation in the first place. In this sense, to occupy Syntagma means not only to physically locate autonomy from social control by state authorities, but to seek autonomy from social control altogether. Therefore, what Irini's dissatisfaction shows is that by producing spaces of resistance, protesters do not merely strive for policy change (as much of social movement research tacitly assumes). Rather, such spaces are expressions of a struggle for alternative sets of norms and orders, what some have called 'prefigurative politics' (van de Sande 2013), 'experiments in living otherwise' (McKay 2005), 'radical political imaginaries' (Hage 2015), or 'radical imagination' (Haiven and Khasnabish 2014). This is to say that with the territorial comes the ideational,

15

Irini, (participant of the Syntagma Square occupation 2011), in discussion with the author,

February 3 2016. My anonymous reviewers rightly pointed to the question of why the development of a quasi-police provision by protesters was so controversial in Athens, but less so in Cairo. I cannot provide a satisfactory answer and I encourage other researchers to pick this question up. My initial guess is that it would make sense to look into a) the fact that Syntagma was influenced by anarchist/ anti-authoritarian thought that is detrimental to the notion of a hierarchy-based monopoly of legitimate force that is inherent to policing, and b) the fact that the intensity and extent of police violence was higher in Tahrir and that the Mubarak regime followed a strategy of producing a security vacuum and chaos from which the regime hoped it would get people to ask for the police to come back in a move to regain popular legitimacy (see Soudias 2014: 122). 
Dimitris Soudias - On the Spatiality of Square Occupations. Lessons from Syntagma and Tahrir

which is part of why contention over space is a direct challenge to state control and authority. What then are the means of territoriality and space production?

On 'Strategies of Power' and 'Tactics of Resistance'

In mainstream social movement studies, the means of protesters and security forces are covered through literature on tactical repertoires (Taylor \& Van Dyke 2004; Tilly 2006) and policing strategies (della Porta and Reitner 2006; see also Earl 2003). In my own work, I found these scholarly notions fruitful for framing the ways in which protesters appropriate territory and produce spaces of resistance (Soudias 2015; 2014). But the epistemological premises of much of the literature on tactical repertoires tends to be a bit functionalist, treating tactics as items in a toolbox from which actors pick and chose the (rationally) most suitable action, albeit restrained by contextual conditions. Instead, I suggest drawing from Michel de Certeau's (2002) work on tactics and strategies in everyday life, as it implies a certain spatiality.

De Certeau distinguishes between strategies and tactics, where the latter is not subordinate to the former, but opposed to it. Strategy is the purview of power, the means of (state) authority. It is a specific kind of knowledge, "one sustained and determined by the power to provide oneself with one's own place" $(2002,36)$. That is to say that crucial to strategy is the possession of territory - a place from which authorities can protect from and plan against the encroachment of dissidents. As illustrated earlier, such places are the locations of power: public buildings and institutions, such as the ministry of interior in Egypt, or the quiet cynically named Greek pendant - the Ministry of Citizen Protection - from where, simply put, authorities can plan the next move. Strategies are able to "produce, tabulate, and impose" spaces (30). Through strategy, authority can reproduce itself "in and through this knowledge" (36). Strategies are enforced by police that are physically present in the streets, supported by a legal framework that dictates the 'proper' or 'orderly' use of space. By policing territory and overseeing (the development of) autonomous spaces, authorities not only maintain and monitor the orderly use of space and ensure their own survival (and that of the state), but also reproduce the imagination of their sovereignty and power.

Tactics of resistance, on the other hand, are means of countering strategies of power, resisting authorities and maintaining lived space. They are the "art of the weak" (37) in that they "manipulate and divert" conceived spaces (30). To use an earlier example, Tahrir is produced by authorities as a traffic junction (conceived space). Making use of tactics for transforming it into a lived space of resistance is a subversive way of manipulating the initial conception of Tahrir in use. "What it wins it cannot keep" (37). This hints at the fact that the terms of resistance are characterized precisely by a lack of safe spaces. Occupations are temporary, as participants themselves acknowledge:

I don't think that there is a place in the world where people thought that the square would last forever ... that we would stay there for four years on the square with the 
tents. ... We stayed there as long as we could and we endured ... with the repression and the violence that existed. ${ }^{16}$

This temporality highlights the limitations of territoriality. De Certeau (2002) notes that "the space of a tactic is the space of the other. Thus it must play on and with a terrain imposed on it and organized by the law" of authorities (37). Due to the lack of its own manifest place, tactic is spontaneous (as it cannot strategize), and needs to take advantage of and depends on opportunities. As Sherif notes regarding tactics in Tahrir:

I think that the tactics that were successfully used by demonstrators were contingent upon the political realities on the ground every day. Tactics that were successful one day, were not successful on other days. ${ }^{17}$

Tactics are therefore situative and responsive.

Before elaborating on protesters' tactics that produce and maintain spaces of resistance, I will take a closer look at policing strategies. Mohammed's account of Tahrir does a good job at summarizing the kinds of strategies security forces employ:

Their plan ... was very simple and organized in certain steps. The first one is to allow them [protesters] to protest and to let them say whatever they want and to observe. The second ... step is to surround them and make sure that they will not ... do anything that will make other people [join]. And then in al-Tahrir square they [protesters] will get [bored] and they will leave. If not, start using teargas at first and then after ... using teargas, start beating and separating them from each other. After that, start using... the Taser and then rubber bullets ... and they used everything. After that they spread some lies: "be careful, some thugs are coming" ... and they put

16

Katerina, (participant of the Syntagma Square occupation 2011), in discussion with the author, October 192014.

17

Sherif, (participant of the Tahrir Square occupation 2011), in discussion with the author, March 20 2011. 
Dimitris Soudias - On the Spatiality of Square Occupations. Lessons from Syntagma and Tahrir

some of their people on the square - because it was open for everyone - they put some people to frighten us and to threaten us. ${ }^{18}$

The first strategy that Mohammed identifies is the gathering of information by security forces, relating to de Certeau's notion of "power of knowledge", from which further strategies can be developed and employed. "To surround them" and hindering people to join occupations is a strategy of (nonviolent) spatial control. By hindering people to join and strategically making use of area, they impede their possibility to territorialize and use and transform space. In both, Syntagma and Tahrir, the metro station below the squares were eventually shut down, impeding people's access to and from the square. In Syntagma, another such strategy participants observed was to change the composition of people in the square. As Viktoria recalls regarding Omonia Square, a frequent gathering point for drug users:

At Omonia, there were no drug addicts. The police went to empty it. They didn't let the drug addicts [back on Omonoia]. They raided the square with various units that were [stationed] in Omonoia, and many drugs came to us. ${ }^{19}$

Through strategies of spatial control, security forces facilitated an influx of drugs into Syntagma, which authorities then used in order to discredit the occupation (see framing strategies below). A further rather typical example of spatial control occurred on the first day of protests in Cairo on January 25. Security forces tried to cordon off Tahrir, but, as mentioned before, the many streets leading to the square and the sheer number of protesters approaching it made it impossible to seal Tahrir off. Security forces eventually had to retreat and open access to the square, allowing protesters to converge there. Instead, they reorganized and cordoned off access to adjacent Qasr al-'Aini Street with an overwhelming security presence, as many ministries, as well as the parliament, are located there. Qasr al-'Aini was off-limits. ${ }^{20}$

Whenever protesters tried to expand their territoriality beyond Tahrir towards Qasr al-'Aini, riot police responded with water hoses, massive amounts of tear gas, and rocks thrown by thugs (Soudias 2014, 114-115). This violent response to territorial expansion relates to what Mohammed described earlier:

18

Mohammed, (participant of the Tahrir Square occupation 2011), in discussion with the author, March 72011.

19

Viktoria, (participant of the Syntagma Square occupation 2011), in discussion with the author, October 222014.

20

Personal observation on January 252011. 
Dimitris Soudias - On the Spatiality of Square Occupations. Lessons from Syntagma and Tahrir

violent strategies, which were most prominent in Tahrir and Syntagma alike. Through the use of force, put simply, the police inflict bodily harm on individuals and groups. By doing so, they impede protesters' capacity to be present, territorialize, and produce spaces of resistance. In the face of an overwhelming amount of people, the police make use of force in order to ensure protesters do not expand their territory to the locations of power (in de Certeau's sense). They also violently intervene into protesters' lived spaces in an attempt to reverse the use of space back to their initial conception. Regarding Syntagma, Vasilis notes that "there were of course arrests and there were beatings, no doubt. But the big focus was on chemical warfare." ${ }^{21}$ During the 48-hour general strike of June 28 and 29 protesting the Greek parliament's vote on the EU's austerity plan and culminating in Syntagma, police threw around 3,000 canisters of teargas in the center of Athens (Dalakoglou 2011). If not protected by a mask, such amounts of gas make it impossible to breath. This bodily harm has spatial consequences, as 55 year old Kyriaki shows:

[When] they throw teargas at you, when you have asthma - because I have also asthma - you cannot stand [your ground]. I mean you get sick! They make you sick. And you say to yourself "I am sick now for a week. Will I go again? How will I go again if they do something like that?" And of course, this is the same with others, I imagine. Who would take the plunge and go ... again? Because this is their [police] tactic. $^{22}$

Violent policing strategies impede protesters' capacity to act, i.e. territorialize and use space. But Vasiliki points also at something else. The (perceived) violence may also keep protesters from being present in future protests/occupations. Alaa's experience illustrates this as well. Returning home from Tahrir Square at night on January 25, Alaa has been arrested by police right by the Egyptian Museum adjacent to the square. After having been shoved in a police truck with others and driven towards a desert road (spatial control), they somehow managed to escape in the chaos of the night. But having lived through this left Alaa frightened:

21

Vasilis, (participant of the Syntagma Square occupation 2011), in discussion with the author, October 242014.

22

Kyriaki, (participant of the Syntagma Square occupation 2011), in discussion with the author, October 192014. 
I didn't go back [to Tahrir]. I was actually afraid. Until now, every time I hear the siren of the police, I get the shivers. That was the worst experience. I kept thinking how they [police] can just put you away and nobody will know about you. ${ }^{23}$

Fear of being subjected to violence keeps protesters from participating, which quite simply can contribute to decreasing the number of participants.

The last strategy Mohamed points to is "spreading lies", referring to framing strategies (see Benford and Snow 2000) that target at discrediting protesters and their occupation as a whole. Although not enforced by security forces directly, but rather by authoritative regime figures, frames supplement policing strategies. After Tahrir was occupied for days, Mubarak (2011) attempted to carefully discredit the occupiers as a violent mob:

Those protests were transformed from a noble and civilised phenomenon of practising freedom of expression to unfortunate clashes, mobilised and controlled by political forces that wanted to escalate and worsen the situation. They targeted the nation's security and stability through acts of provocation, theft, and looting, and setting fires, and blocking roads, and attacking vital installations and public and private properties, and storming some diplomatic missions.

Such framing strategies may have little impact on those already occupying public space (as they 'know' from their presence in the occupations that these frames are not 'real'), but they try to - however unsuccessful in this specific case - keep a wider audience from joining by turning popular opinion against protesters.

As we have seen in previous examples, strategies can be combined in various ways and all aim at returning to a spatiality of public order, quelling dissent through social control. However, there is no guarantee that they are effective in doing so, as Lukas' case adequately illustrates:

You had massive violence there [Syntagma]. You swallowed tons of chemicals to the point of suffocation. You saw a lot of blood around you. You were beaten. You were also arrested. ... You know that your face is ... in the computers of the police.

23

Alaa, (participant of the Tahrir Square occupation 2011), in discussion with the author, December 12014. 
Dimitris Soudias - On the Spatiality of Square Occupations. Lessons from Syntagma and Tahrir

... To have been recorded by police is a type of repression: "Stay home!" For me, it didn't repress me. It liberated me! ${ }^{24}$

Protesters resist police territorialization through their very own territorialization and spatiality. Returning to de Certeau (2002), they do so through tactics of resistance. The transformation of Syntagma and Tahrir from traffic hubs to protest encampments happened mostly through what I would like to call space-making practices, which can be seen as tactics of transforming and maintaining spaces of resistance. The setting up of groups and infrastructure (such as clinics or a storerooms for items) discussed earlier and the showcasing of banners and posters are an example of this. Other examples include such maintenance procedures as the cleaning of the squares, highlighting protesters' claim to ownership. On June 15, after a battle between protesters and police that lasted for hours, Syntagma square was covered in white dust from all the teargas. As people returned to the square after the fighting (as they always did), they started to clean the square, making use of the fountain in the heart of Syntagma:

[...] a chain was created from the fountain; a human chain from the fountain to the top [of the square]. We filled up small bottles with water and one gave it to the next and we threw water on the ground on the upper [square], where there was a mess from the chemicals. We wanted the chemicals to not get up in the air. ${ }^{25}$

By cleaning the square, protesters not only maintain their occupation, but also emphasize their claim to territory. As Andreas remarks, the cleaning of the square was important because "it shows again the willingness of the people to maintain the thing that they have."26

In the face of perpetual police force, the question of whether to use violence was a contentious issue amongst protesters. Tahrir was intended as a peaceful and non-violent encampment and has been framed as such (Lindsey 2011). But protesters did in fact make use of violent tactics, beating up thugs and even establishing a makeshift prison inside the Sadat metro station. On such crucial days as February 2 -

24

Lukas, (participant of the Syntagma Square occupation 2011), in discussion with the author, February 232016.

25

Katerina, (participant of the Syntagma Square occupation 2011), in discussion with the author, October 192014.

26

Andreas, (participant of the Syntagma Square occupation 2011), in discussion with the author, February 112016. 
when Tahrir was attacked by an amalgam of thugs, plainclothes police, supporters of Mubarak, and horses and camels - protesters may not have kept the square if it was not for their engaging in violent battles (Soudias 2014, 122-127). Violence therefore did play an important role for holding on to Tahrir. And it did so too in Syntagma. When asked about violence, participants were overly keen on legitimating violent tactics as a necessary evil, as Thodoris shows:

I'm not saying you should go around killing people. But ... when you have been attacked by the police and ... there's a libel against you every day in the media, and you go through all these things and you happen to be beaten up and arrested, teargased and shit like that, you can't actually say that what's important is peace. ${ }^{27}$

In the face of perpetual police violence, the barrier against the use of force shrunk, as Lukas acknowledges in a group discussion:

So, alright, it's a nice message [referring to nonviolence]. But in practice, on the streets, on the 15th we got beaten. On the 16th we got beaten again. On the 27th, or rather on the 28th of June: "Should we maybe ALSO throw one [stone]?" On the 29th, guys, things weren't pacifist. Half the square was with the black bloc and got into fights with the cops! We were there, we saw that ${ }^{28}$

In both Syntagma and Tahrir there were defense groups fighting off intruders. By use of Molotov cocktails, sticks, or rocks, protesters tried to thwart attacks. They also threw or kicked back teargas canisters, lit trashcans as burning barricades and broke plenty of pavement open to be used as rocks. At some point, however, violence got endemic in Syntagma, as Viktoria acknowledged:

Violence is a virus. With the outbreak of the first violence, the people gut stubborn. They wanted to go down, create a panic and "eat the cops", let's say. I mean, from one point on, our assemblies changed and we talked about what we will do to the

27

Thodoris, (participant of the Syntagma Square occupation 2011), in discussion with the author, October 172014.

28

Lukas (participant of the Syntagma Square occupation 2011), in a group discussion including the author, March 282016. 
Dimitris Soudias - On the Spatiality of Square Occupations. Lessons from Syntagma and Tahrir

cops. How we will defend ourselves, how we will keep the square. So we got into war-like situation.

This highlights the interactive nature of spatial contestation. The violent intervention of security forces into protesters' lived space of resistance impacted the composition and discourses of the latter. In that sense, policing strategies were successful in transforming Syntagma into a "war-like" space, away from its production as a space of radical imagination.

But not all of the protesters' efforts to thwart off police and maintain the occupation were violent. There were also nonviolent tactics, such as the use of masks and medication, especially Maalox or Riopan (against the ramifications of teargas) ensuring that people can be present, can hold on. There are also more subversive tactics, violent and nonviolent, working as trickery. Around Tahrir, for example, I observed people taking batteries out of police trucks in order to impede the mobility of security forces. In Syntagma, laser pointers were used frequently to blind the police. Or, as Dimitris recalls, some protesters

clog the filters of the [police] masks with fire extinguishers. We spray them at the squads. They clog the filters and they can't move forward. They can't see either. And they're stuck ... So whenever we [used] fire extinguishers ..., you saw the entire [police] squad going back.

\section{Conclusion}

In this article, I tried to rethink the notion of spatiality with regards to square occupations beyond their physical characteristics. By means of bricolage, I tried to shed light on the relationship between space, place, presence, and territoriality as constitutive parts of this spatiality. Protesters chose central squares such as Syntagma or Tahrir as their locus of discontent due to their political, historical, and physical characteristics. By appropriating squares, setting up structures (such as tents) and interacting with each other (and in turn with space), protesters transform these squares from their initial conception towards lived spaces of resistance. By being present in these squares over a prolonged period of time (Stasis), protesters territorialize their occupations i.e. claim ownership over territory and physically locate autonomy away from state authorities.

The means of producing and transforming spaces are tactics of resistance and strategies of power. De Certeau's exploration helps us ground tactics and strategies more (meta-)theoretically beyond their use as functional tools and contextualizes them within the production and contestation of space. Protesters want to change the status quo, making use of tactics to transform and manipulate squares into spaces of resistance. These tactics can be violent and nonviolent and make use of what de Certeau calls "trickery." The production and maintenance of spaces of resistance on authorities' home turf is therefore prerequisite, 
Dimitris Soudias - On the Spatiality of Square Occupations. Lessons from Syntagma and Tahrir

expression, and consequence of social change, one that shakes political elites. The police, as agents of territoriality and social control, try to prevent protesters from doing so. In trying to maintain the status quo, they make use of policing strategies in order to ensure public order. They do so because the contention over space is a direct challenge to state control and authority. Policing strategies in Cairo and Athens alike were overwhelmingly marked by violence. This hints at the fact that when the status quo is seriously under threat and authorities in jeopardy, violence appears to be the primary policing choice — regardless of whether the political systems are labeled authoritarian or democratic.

\section{References}

Abdelrahman, Maha. 2015. Egypt's Long Revolution. Protest Movements and Uprisings. Milton Park \& New York: Routledge.

AlSayyad, Nezar. 2011. Interview with Aaron Britt. Design and History of Tahrir Square. Dwell. Retrieved from: https://www.dwell.com/collection/design-and-history-of-tahrir-square-1526b353

Anderson, Malcolm. 2011. In Thrall to Political Change. Police and Gendarmerie in France. Oxford: Oxford University Press.

Bamyeh, Mohammed A. 2013. "Anarchist Method, Liberal Intention, Authoritarian Lesson: The Arab Spring between Three Enlightenments." Constellations 20 (2):188-202.

Bayat, Asef. 2009. Life as Politics. How Ordinary People Change the Middle East. Cairo: The American University in Cairo Press.

Benford, Robert D., and David A. Snow. 2000. "Framing Processes and Social Movements: An Overview and Assessment." Annual Review of Sociology 26:611-639.

Crang, Mike, and Nigel Thrift, eds. 2000. Thinking Space. London: Routledge.

Dalakoglou, Dimitris. 2011. "The Irregularities of Violence in Athens." Cultural Anthropology. Retrieved from: https://culanth.org/fieldsights/251-the-irregularities-of-violence-in-athens

de Certeau, Michel. 2002. The Practice of Everyday Life. Translated by Steven Rendall. 2nd ed. Berkeley $\&$ Los Angeles: University of California Press.

della Porta, Donnatella, Abby Peterson, and Herbert Reiter, eds. 2006. The Policing of Transnational Protest. Aldershot: Ashgate.

Douzinas, Costas. 2013. Philosophy and Resistance in the Crisis. Cambridge: Polity Press.

Douzinas, Costas. 2012. "Athens Rising." European Urban and Regional Studies 20 (1):134-138.

Earl, Jennifer. 2003. "Tanks, Tear Gas, and Taxes: Toward a Theory of Movement Repression." Sociological Theory 21 (1):44-68. 
Dimitris Soudias - On the Spatiality of Square Occupations. Lessons from Syntagma and Tahrir

Elden, S. 2004. Understanding Henri Lefebvre. Theory and the Possible. London \& New York: Continuum.

Foucault, Michel. 1986. "Of Other Spaces." Diacritics 16 (1):22-27.

Gieryn, Thomas F. 2000. "A Space for Place in Sociology." Annual Review of Sociology 26:463-493.

Giovanopoulos, Christos, and Dimitris Mitropoulos, eds. 2011. Democracy under Construction. From the Streets to the Squares. Athens: A/Synechia. (in Greek).

Gottdiener, Mark, and Ray Hutchinson. 2010. The New Urban Sociology. 4th ed. Boulder: Westview Press. Haiven, Max, and Alex Khasnabish. 2014. The Radical Imagination. London: Zed Books.

Hage, Ghassan. 2015. Alter-Politics. Critical Anthropology and the Radical Imagination. Melbourne: Melbourne University Press.

Harmanşah, Ömür. 2014. "Urban Utopias and How They Fell Apart: The Political Ecology of Gezi Park1." The Making of a Protest Movement in Turkey: \#occupygezi, edited by Umut Özkırıml, 122-133. Houndmills: Palgrave Macmillan.

Herbert, Steve. 1997. Policing Space. Territoriality and the Los Angeles Police Department. Minneapolis $\&$ London: University of Minnesota Press.

Korany, Bahgat, and Rabab El-Mahdi, eds. 2012. Arab Spring in Egypt. Revolution and Beyond. Cairo \& New York: The American University in Cairo Press.

Lefebvre, Henri. 2007. The Production of Space. Translated by Donald Nicholson-Smith. 2nd ed. Oxford: Blackwell.

Lindsey, Ursula. 2011. "Revolution and Counter-Revolution in the Egyptian Media." Retrieved from: http://www.merip.org/mero/mero021511.

Löw, Martina. 2008. "The Constitution of Space: The Structuration of Spaces Through the Simultaneity of Effect and Perception." European Journal of Social Theory 11 (1):25-49.

Marom, Nathan. 2013. "Activising Space: The Spatial Politics of the 2011 Protest Movement in Israel." Urban Studies 50 (13):1-16.

Martin, D. G., \& Miller, B. 2003. "Space and Contentious Politics. " Mobilization, 8(2), 143-156.

Massey, Doreen. 1996. "Politicising Space and Place." Scottish Geographical Magazine 112 (2):117-123.

McKay, Ian. 2005. Rebels, Reds, Radicals: Rethinking Canada's Left History. Toronto: Between the Lines. Hosni Mubarak's speech: full text. (2011, February 2). The Guardian. Retrieved from http://www.theguardian.com/world/2011/feb/02/president-hosni-mubarak-egypt-speech 
Dimitris Soudias - On the Spatiality of Square Occupations. Lessons from Syntagma and Tahrir

Ramadan, Adam. 2012. "From Tahrir to the world: The camp as a political public space." European Urban and Regional Studies 20 (1):145-149.

Sack, Robert D. 1993. "The Power of Place and Space." Geographical Review 83 (3):326-329.

Sack, Robert D. 1986. Human Territoriality: Its Theory and History. Cambridge: Cambridge University Press.

Schumann, Christoph, and Dimitris Soudias. 2013. " Präsenz und Raum in der Arabischen Revolte. Ägypten im Jahr 2011. " In Präsenz und implizites Wissen: Zur Interdependenz zweier Schlüsselbegriffe der Kultur- und Sozialwissenschaften, edited by Christoph Ernst and Heike Paul, 297-315. Bielefeld: Transcript.

Soja, Edward W. 1980. "The Socio-Spatial Dialectic." Annals of the Association of American Geographers $70(2): 207-225$.

Soudias, Dimitris. 2015. "Policing January 25: Protest, Tactics, and Territorial Control in Egypt's 2011 Uprising." Middle East-Topics \& Arguments 4:170-182. doi: 10.17192/meta.2015.4.2669.

Soudias, Dimitris. 2014. Negotiating Space. The Evolution of the Egyptian Street, 2000-2011. Cairo \& New York: The American University in Cairo Press.

Souliotis, Nicos. 2013. "Athens and the Politics of the Sovereign Debt Crisis. " In Cities and Crisis. New Critical Urban Theory, edited by Kuniko Fujita, 237-270. London \& Thousand Oaks: Sage.

Stavrides, Stavros. 2012. "Squares in Movement." The South Atlantic Quarterly 111 (3):585-596.

Stavrou, Achilleas. 2011. "The "Upper Square" or when the Masses speak. "Oe, Oe, Oe, they got off the couch"." In Democracy under Construction. From the Streets to the Squares, edited by Christos Giovanopoulos and Dimitris Mitropoulos, 31-40. Athens: A/Synechia. (in Greek).

Taylor, Verta, and Nella Van Dyke. 2004. ""Get up, Stand up": Tactical Repertoires of Social Movements." In The Blackwell Companion to Social Movements, edited by David A. Snow, Sarah A. Soule and Hanspeter Kriesi. Oxford: Blackwell.

Telmissany, May. 2014. "The utopian and dystopian functions of Tahrir Square." Postcolonial Studies 17 (1):36-46.

Tilly, Charles. 2006. Regimes and Repertoires. Chicago: The University of Chicago Press.

Turner, Stephen. 2014. "Mundane Theorizing, Bricolage, and Bildung." In Theorizing in Social Science. The Context of Discovery, edited by Richard Swedberg, 131-157. Stanford: Stanford University Press.

van de Sande, Mathijs. 2013. "The Prefigurative Politics of Tahrir Square-An Alternative Perspective on the 2011 Revolutions." Res Publica 19 (3):223-239. 
Dimitris Soudias - On the Spatiality of Square Occupations. Lessons from Syntagma and Tahrir

Wahlström, Mattias. 2010. "Producing spaces for representation: racist marches, counterdemonstrations, and public-order policing." Environment and Planning D: Society and Space 28:811-827. 